\title{
ANALISIS SERTIFIKASI DOSEN DAN MOTIVASI KERJA TERHADAP KEPUASAN KERJA DAN KINERJA DOSEN PADA UNIVERSITAS SWASTA DI KOTA PALEMBANG
}

\author{
Suhada, SE., M.M., Nisa' Ulul Mafra, S.E., M.Si., Santi Puspita, S.E., M.Si \\ Jurusan Manajemen, Fakultas Ekonomi, Universitas PGRI Palembang \\ Jalan A. Yani Lrg. Gotong Royong 9/10 Ulu Plaju, Palembang
}

\begin{abstract}
ABSTRAK
Penelitian ini bertujuan untuk menguji hipotesis dan menganalisis pengaruh sertifikasi dosen dan motivasi kerja terhadap kepuasan kerja dan kinerja dosen pada Universitas Swasta di Kota Palembang. Populasi dalam penelitian ini berjumlah 560 orang dosen Universitas Swasta di Kota Palembang yang telah menerima sertifikasi dosen, sedangkan sampel data berjumlah 85 orang dosen. Analisis data penelitian menggunakan metode statistik deskriptif dan inferensial. Model analisis menggunakan Path Analysis (analisis jalur) dengan komposisi sub-struktur : Sertifikasi dosen dan Motivasi Kerja sebagai variabel eksogen dan Kepuasan Kerja sebagai variabel endogen. Selanjutnya komposisi struktur terdiri dari Sertifikasi dosen, Motivasi Kerja dan Kepuasan Kerja sebagai variabel eksogen dan Kinerja Dosen sebagai variabel endogen.

Kesimpulan secara umum adalah : (1) Terdapat pengaruh positif dan signifikan sertfikasi dosen dan motivasi kerja secara bersama-sama terhadap kepuasan kerja dosen Universitas Swasta di Kota Palembang. Hal ini ditunjukkan dengan persamaan sub-struktural : kepuasan kerja $=0,365$ sertifikasi dosen $+0,211$ motivasi kerja. (2) Terdapat pengaruh positif dan signifikan sertfikasi dosen, motivasi kerja dan kepuasan kerja secara bersama-sama terhadap kinerja dosen Universitas Swasta di Kota Palembang. Hal ini ditunjukkan dengan persamaan struktural : kinerja dosen $=0,426$ sertifikasi dosen $+0,211$ motivasi kerja $+0,210$ kepuasan kerja.

Untuk meningkatkan kepuasan kerja dosen, dapat dilakukan dengan meningkatkan sertifikasi dosen terlebih dahulu, baru setelah itu motivasi kerja. Kemudian untuk meningkatkan kinerja dosen, dapat dilakukan dengan meningkatkan sertifikasi dosen terlebih dahulu, kemudian kepuasan kerja dan baru setelah itu motivasi kerja.
\end{abstract}

Kata Kunci : Sertfikasi Dosen, Motivasi Kerja, Kepuasan Kerja dan Kinerja Dosen.

\section{PENDAHULUAN Latar Belakang}

Permasalahan

pada

universitas swasta di Kota Palembang adalah kinerja dosen yang telah memperoleh sertifikasi dosen belum optimal ditinjau dari Tri Dharma Perguruan Tinggi yaitu pendidikan dan pengajaran, penelitian, dan pengabdian kepada masyarakat.

$$
\text { Dalam melaksanakan }
$$

pendidikan dan pengajaran beberapa dosen yang telah tersertifikasi belum menunjukkan peningkatan kinerja yang signifikan, misalnya masih belum memiliki persiapan mengajar seperti silabus, satuan acara perkuliahan, skenario mengajar, ketidakdisiplinan mengajar, dan kurang produktivitasnya dalam membuat bahan ajar dan buku ajar.

Selain itu dalam kaitannya dengan masalah penelitian fakta yang didapatkan menunjukkan bahwa jumlah dosen dalam melaksanakan penelitian baik oleh masing-masing dosen (secara perorangan) maupun secara berkelompok masih rendah. Dari observasi awal penyebab rendahnya penelitian diduga dipengaruhi oleh faktor-faktor sebagai berikut (1) Lemahnya kemampuan dosen menyusun proposal penelitian, (2) Kurang tersedianya dana dari yayasan yang menaunginya, Kurang memadainya fasilitas kegiatan penelitian, meliputi internet, literatur

*) Dosen Tetap Fakultas Ekonomi UPGRI Palembang 
dan laboratorium, (4) Lemahnya budaya meneliti di kampus.

$$
\text { Dalam bidang pengabdian }
$$

kepada masyarakat pelaksanaannya dalam kurun waktu lima tahun terakhir ini ternyata jarang dilakukan oleh para dosen sebagian Universitas Swasta di kota Palembang yang antara lain alasan yang dikemukakan oleh para dosen tersebut adalah karena terbentur tidak ada dana yang dialokasikan oleh yayasan, maka hal ini yang menyebabkan dosen tidak termotivasi untuk melaksanakan kegiatan pengabdian kepada masyarakat.

Beberapa peneliti telah meneliti tentang pengaruh sertifikasi, motivasi, kepuasan kerja dan kinerja diantaranya Murwati (2013), Romli (2012), Partono \& Nurmawati, Ira (2010), Melati, dkk (2013), Zulkifli, dkk (2014), Syahalam, dkk (2013), Diana (2012), Suwandi (2012), Indrarini (2009), Istiarini, R. \& Sukanti. (2012) serta Kanto (2015).

Hubungan mengenai setifikasi terhadap kinerja telah dilakukan oleh beberapa peneliti, seperti Murwati (2013), Romli (2012), Partono \& Nurmawati, Ira (2010), Zulkifli , dkk (2014), Suwandi (2012), Kanto (2015) serta Istiarini, R. \& Sukanti. (2012). Hasil penelitian tersebut menyatakan bahwa sertifikasi berpengaruh terhadap kinerja.

Hubungan mengenai motivasi terhadap kinerja telah dilakukan oleh beberapa peneliti, seperti Indrarini (2009), Zulkifli , dkk (2014), Suwandi (2012), Kanto (2015) serta Istiarini, R. \& Sukanti (2012). Hasil penelitian tersebut menyatakan bahwa motivasi berpengaruh terhadap kinerja. Berbeda dengan hasil penelitian yang dilakukan oleh Syahalam, dkk (2013), hasil penelitiannya menunjukkan bahwa motivasi tidak berpengaruh terhadap kinerja.
Hubungan

mengenai kepuasan kerja terhadap kinerja telah dilakukan oleh beberapa peneliti, seperti Indrarini (2009), Syahalam, dkk (2013), Diana (2012) serta Kanto (2015). Hasil penelitian tersebut menyatakan bahwa kepuasan kerja berpengaruh terhadap kinerja.

Berdasarkan uraian latar belakang di atas, maka penelitian ini bermaksud mengungkap bagaimana kinerja dosen Universitas Swasta di Kota Palembang dan bagaimana faktor sertifikasi dosen dan motivasi kerja dosen yang dimiliki berpengaruh terhadap kepuasan kerja dan kinerja dosen Universitas Swasta di Kota Palembang.

\section{Rumusan Masalah}

Berdasarkan latar belakang di atas, maka dapat dirumuskan masalah sebagai berikut:

a. Apakah ada pengaruh sertifikasi dosen dan motivasi kerja baik secara parsial maupun secara bersama-sama terhadap kepuasan kerja pada Universitas Swasta di Kota Palembang?

b. Apakah ada pengaruh sertifikasi dosen, motivasi kerja dan kepuasan kerja secara parsial terhadap kinerja dosen pada Universitas Swasta di Kota Palembang?

c. Apakah ada pengaruh sertifikasi dosen, motivasi kerja terhadap kinerja dosen melalui kepuasan kerja pada Universitas Swasta di Kota Palembang?

\section{TINJAUAN PUSTAKA Sertifikasi Dosen}

Sertifikasi menurut undangundang No 14 Tahun 2005 tentang guru dan dosen adalah proses pemberian sertifikat oleh lembaga yang ditetapkan pemerintah kepada tenaga pendidik yang memenuhi 
kualifikasi persyaratan. Pada pasal 45 Dosen wajib memiliki kualifikasi akademik, kompetensi, sertifikat pendidik, sehat jasmani dan rohani, dan memenuhi kualifikasi lain yang dipersyaratkan satuan pendidikan tinggi tempat bertugas, serta memiliki kemampuan untuk mewujudkan tujuan pendidikan nasional.

\section{Motivasi}

Motivasi kerja adalah sesuatu yang menimbulkan semangat atau dorongan kerja. Oleh sebab itu, motivasi kerja dalam psikologi kerja biasa disebut pendorong semangat kerja. Kuat dan lemahnya motivasi kerja seorang tenaga kerja ikut menentukan besar kecilnya prestasinya (Anoraga, 2014: 35).

\section{Kepuasan Kerja}

Menurut Hasibuan (2013 : 202), kepuasan kerja adalah sikap emosional yang menyenangkan dan mencintai pekerjaannya, sikap ini dicerminkan oleh moral kerja, kedisiplinan dan prestasi kerja. Kepuasan kerja dinikmati dalam pekerjaan, luar pekerjaan, dan kombinasi dalam dan luar pekerjaan.

\section{Kinerja Dosen}

Kinerja merupakan suatu hasil kerja yang dicapai seorang dalam melaksanakan tugas-tugas yang dibebankan kepadanya berdasarkan kecakapan, kesanggupan, pengalaman, dan waktu (Rivai, 2009: 125).

\section{METODE PENELITIAN Rancangan Penelitian}

Berdasarkan jenis dan pendekatan penelitian, maka penelitian ini termasuk dalam kategori penelitian kuantitatif, yaitu penelitian yang bertujuan untuk mengukur data dan menerapkan beberapa bentuk analisis statistik. Penelitian ini menguji pengaruh variabel bebas terhadap variabel terikat.

\section{Populasi dan Sampel}

Populasi dalam penelitian ini adalah dosen yang telah memperoleh sertifikasi pada Universitas Swasta di kota Palembang berjumlah 560 orang dari 9 Universitas yang ada di Kota Palembang, teknik pengambilan sampel menggunakan teknik sampel acak terstratifikasi (stratified random sampling), yakni mengambil sampel secara acak proporsional dari masingmasing kelompok yang ada di masingmasing Universitas Swasta di kota Palembang. Penentuan jumlah sampel dari populasi dikembangkan menurut Slovin, sehingga jumlah sampel yang diambil sebanyak 85 orang dosen, sampel yang diambil secara proporsi berdasarkan jumlah dosen yang ada di universitas masing-masing.

\section{Teknik Pengumpulan Data}

Teknik pengumpulan data yang digunakan dalam penelitian ini dengan menggunakan kuesioner. Kuesioner yang digunakan dalam penelitian ini adalah jenis tertutup dalam bentuk check list, dan guna mempermudah pengukuran data yang diperoleh dari responden, digunakan skala likert skala 1 sampai 5 .

\section{Pengujian Instrumen Penelitian}

Uji coba instrumen bertujuan untuk mendapatkan kuesioner yang valid dan reliabel. Uji validitas instrumen dilakukan menggunkan korelasi product moment atau pearson correlation. Kemudian untuk melihat andal tidaknya suatu alat ukur digunakan pendekatan secara statistika menggunakan metode AlphaCronbacnh. 


\section{Pengujian Aumsi Klasik}

Untuk memperolah nilai koefisien yang tidak bias dan efisien dari persamaan estimasi menggunakan OLS, maka pelaksanaannya data yang diperoleh harus memenuhi beberapa persyaratan analisis jalur meliputi data berskala interval, berdistribusi normal, pemenuhan asumsi, normalitas, terbebas dari masalah multikolinieritas dan heteroskedasitas.

\section{Model Analisis}

Pada penelitian ini menggunakan model Analisis Jalur (Path Analysis). Menurut Webley sebagaimana dikutip Pardede (2014) analisis jalur merupakan pengembangan langsung bentuk regresi berganda dengan tujuan untuk memberikan estimasi tingkat kepentingan (magnitude) dan signifikansi (significance) hubungan sebab akibat hipotetikal dalam seperangkat variabel.

Bentuk penelitian analisis jalur merupakan metode analisis data multivariat dengan tujuan mengetahui pengaruh langsung dan tidak langsung maupun pengaruh total beberapa variabel penyebab (eksogen) terhadap variabel endogen (akibat) dengan pola hubungan antar variabel adalah satu arah dan semua variabel dapat diobservasi langsung.

\section{HASIL DAN PEMBAHASAN}

\section{Pengujian Instrumen}

Tabel 1. Rekapitulasi Hasil Uji Validitas

\begin{tabular}{lcc}
\hline \multicolumn{1}{c}{ Variabel } & Item & Nilai $\mathbf{r}_{\text {hitung }}$ \\
\hline Serttifikasi Dosen $\left(\mathrm{X}_{1}\right)$ & 10 & $0,451 \mathrm{~s} / \mathrm{d} 0,906$ \\
Motivasi Kerja $\left(\mathrm{X}_{2}\right)$ & 10 & $0,367 \mathrm{~s} / \mathrm{d} 0,766$ \\
Kepuasan Kerja $(\mathrm{Z})$ & 8 & $0,439 \mathrm{~s} / \mathrm{d} 0,805$ \\
Kinerja Dosen $(\mathrm{Y})$ & 9 & $0,570 \mathrm{~s} / \mathrm{d} 0,824$ \\
\hline Sumber : Data primer yang diolah 2017
\end{tabular}

Berdasarkan tabel 1 untuk keempat variabel yaitu sertifikasi dosen, motivasi kerja, kepuasan kerja dan kinerja dosen seluruh pernyataan diperoleh nilai rhitung lebih besar dari rtabel $(0,361)$. Dengan demikian dapat disimpulkan bahwa semua butir pernyataan dari keempat variabel tertsebut dinyatakan valid dan dapat digunakan untuk penelitian selanjutnya

Tabel 2. Rekapitulasi Hasil Uji Reliabilitas

\begin{tabular}{lcc}
\hline \multicolumn{1}{c}{ Variabel } & $\begin{array}{c}\text { Cronbach's } \\
\text { Alpha }\end{array}$ & $\begin{array}{c}\text { Batas } \\
\text { Kritis }\end{array}$ \\
\hline Serttifikasi Dosen $\left(\mathrm{X}_{1}\right)$ & 0,788 & 0,6 \\
Motivasi Kerja $\left(\mathrm{X}_{2}\right)$ & 0,775 & 0,6 \\
Kepuasan Kerja $(\mathrm{Z})$ & 0,750 & 0,6 \\
Kinerja Dosen $(\mathrm{Y})$ & 0,857 & 0,6 \\
\hline
\end{tabular}

Sumber : Data primer yang diolah 2017

Berdasarkan tabel 2 hasil pengujian data reliabilitas, maka dapat disimpulkan untuk keempat variabel memiliki Nilai Cronbach's di atas 0,6 pada taraf nyata alpha $=5 \%$. Dengan demikian dapat disimpulkan semua item pertanyaan yang ada pada instrumen tersebut dinyatakan reliable dan dapat dijadikan sebagai alat ukur dalam analisis selanjutnya.

Pengujian Asumsi Klasik Tabel 3. Hasil Pengujian Normalitas

\begin{tabular}{lcc}
\hline \multicolumn{1}{c}{ Variabel } & K-S-Z & $\begin{array}{c}\text { Nilai } \\
\text { Batasi }\end{array}$ \\
\hline Serttifikasi Dosen $\left(\mathrm{X}_{1}\right)$ & 0,070 & 0,05 \\
Motivasi Kerja $\left(\mathrm{X}_{2}\right)$ & 0,532 & 0,05 \\
Kepuasan Kerja $(\mathrm{Z})$ & 0,128 & 0,05 \\
Kinerja Dosen $(\mathrm{Y})$ & 0,057 & 0,05 \\
\hline
\end{tabular}

Sumber : Data primer yang diolah 2017

Berdasarkan tabel 3 hasil uji normalitas data menggunakan One Sample Kolmogorov Smirnov Test, dapat disimpulkan bahwa semua variabel memiliki data normal, hal tersebut dikarenakan semua data tersebut memiliki Asymp. Sig > (a) 0,05 . 
Uji Multikolinearitas

Tabel 4. Hasil Uji Multikolinearitas

\begin{tabular}{lcc}
\hline \multicolumn{1}{c}{ Variabel bebas } & Tolerance & VIF \\
\hline Serttifikasi Dosen $\left(\mathrm{X}_{1}\right)$ & 0.848 & 1.179 \\
Motivasi Kerja $\left(\mathrm{X}_{2}\right)$ & 0.935 & 1.070 \\
Kepuasan Kerja $(\mathrm{Z})$ & 0.804 & 1.244 \\
\hline Sumber : Data primer yang diolah 2017 &
\end{tabular}

Berdasarkan tabel 4 hasil uji multikolinearitas diperoleh nilai Variance Inflation Factor (VIF) pada semua variabel independen berada tidak jauh dari nilai 1 atau lebih kecil dari 10 dan angka tolerance mendekati 1 maka dapat diambil kesimpulan bahwa tidak terdapat gejala multikolinearitas, sehingga regresi sah untuk digunakan.

\section{Uji Heteroskedastisitas}

Tabel 5. Hasil Pengujian Heterokedastisitas

\begin{tabular}{lcc}
\hline \hline $\begin{array}{c}\text { Variabel } \\
\text { Independen }\end{array}$ & $\begin{array}{c}\text { Residual } \\
\text { Sig. (2-Tailed) }\end{array}$ & $\begin{array}{c}\text { Nilai } \\
\text { Batas }\end{array}$ \\
\hline Serttifikasi Dosen & 0,181 & 0,05 \\
Motivasi Kerja & 0,777 & 0,05 \\
Kepuasan Kerja & 0,564 & 0,05 \\
\hline \multicolumn{2}{l}{ Sumber : Data primer yang diolah 2017 }
\end{tabular}

Berdasarkan tabel 5 hasil uji heteroskedastisitas dengan menggunakan uji koefisien korelasi spearman's rho dapat dilihat bahwa korelasi antara variabel dengan absolut residual memiliki nilai signifikan lebih dari 0,05. Karena signifikansi lebih besar daripada 0,05, maka dapat disimpulkan bahwa tidak terjadi problem heteroskedasitas.

\section{Pengujian Analisis Jalur (Path Analysis)}

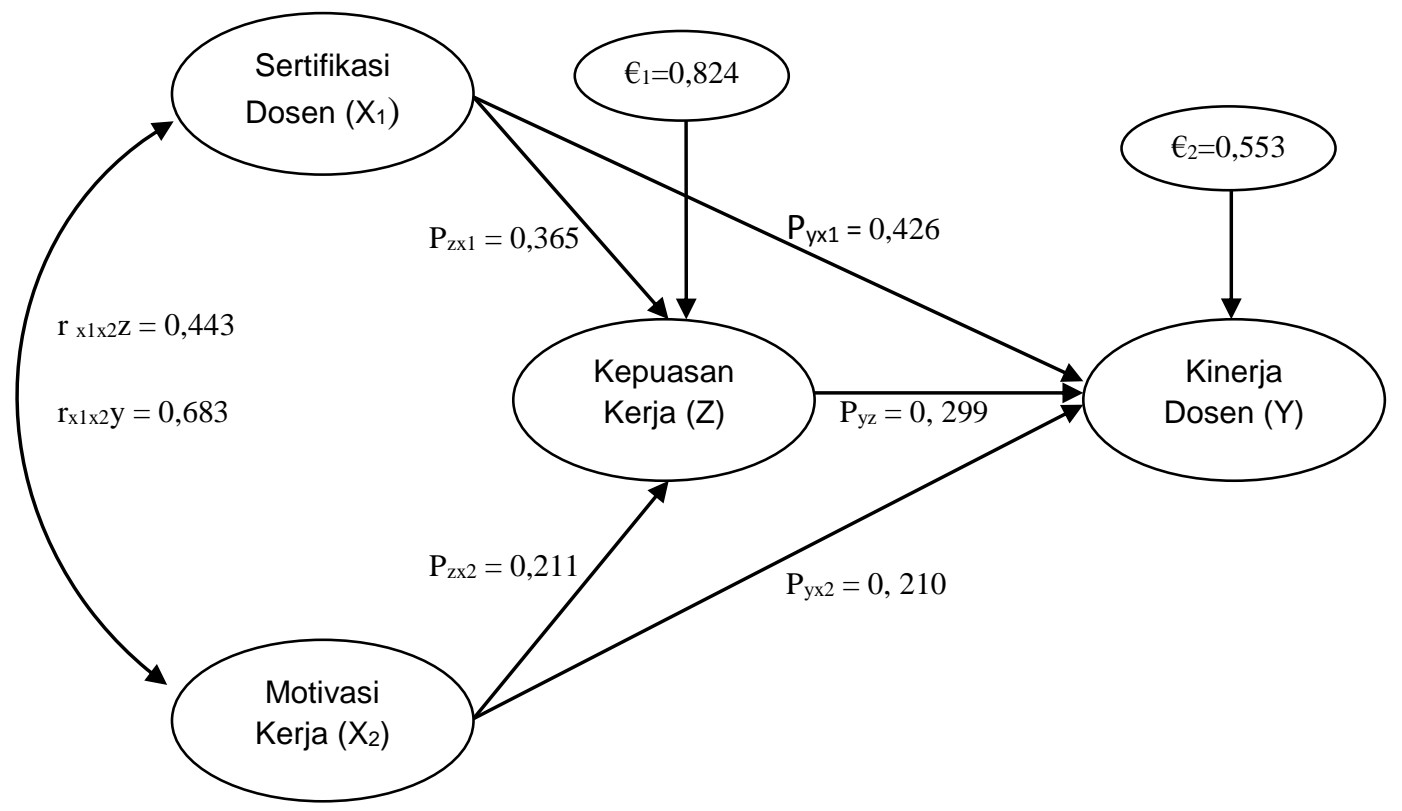

Gambar 1. Nilai Koefisien Jalur dengan Struktur Lengkap

Analisis Persamaan Sub-Struktur

Berdasarkan gambar 1, maka persamaan sub-struktur dalam penelitian ini adalah :

$$
Z=0,365 X_{1}+0,211 X_{2}+0,824 \epsilon_{1}
$$

Model tersebut menunjukkan bahwa nilai besaran koefisien regresi $p_{z x 1}$ sebesar 0,365 dapat diartikan bahwa sertifikasi dosen $\left(X_{1}\right)$ berpengaruh positif terhadap kepuasan kerja (Z). Hal ini menunjukkan bahwa apabila sertifikasi dosen mengalami peningkatan sebesar satu-satuan, maka kepuasan kerja mengalami peningkatan sebesar 0,365 satuan. Nilai besaran koefisien regresi $p_{z x 2}$ sebesar 0,211 dapat diartikan bahwa motivasi kerja $\left(\mathrm{X}_{2}\right)$ berpengaruh positif 
terhadap kepuasan kerja (Z). Hal ini menunjukkan bahwa apabila motivasi kerja mengalami peningkatan sebesar satu-satuan, maka kepuasan kerja mengalami peningkatan sebesar 0,211 satuan.

\section{Analisis Persamaan Struktur}

Berdasarkan gambar.1, maka persamaan struktur dalam penelitian ini adalah :

$$
Y=0,426 X_{1}+0,210 X_{2}+0,299 Z
$$
$+0,553 \epsilon_{2}$

Model tersebut menunjukkan bahwa nilai besaran koefisien regresi $p_{y \times 1}$ sebesar 0,426 dapat diartikan bahwa sertifikasi dosen $\left(X_{1}\right)$ berpengaruh positif terhadap kinerja dosen (Y). Hal ini menunjukkan bahwa apabila sertifikasi dosen mengalami peningkatan sebesar satu-satuan, maka kinerja dosen mengalami peningkatan sebesar 0,426 satuan. Nilai besaran koefisien regresi $p_{y x 2}$ sebesar 0,210 dapat diartikan bahwa motivasi kerja $\left(\mathrm{X}_{2}\right)$ berpengaruh positif terhadap kinerja dosen (Y). Hal ini menunjukkan bahwa apabila motivasi kerja mengalami peningkatan sebesar satu-satuan, maka kinerja dosen mengalami peningkatan sebesar 0,210 satuan. Nilai besaran koefisien regresi pyz sebesar 0,299 dapat diartikan bahwa kepuasan kerja (Z) berpengaruh positif terhadap kinerja dosen $(Y)$. Hal ini menunjukkan bahwa apabila kepuasan kerja mengalami peningkatan sebesar satu-satuan, maka kinerja dosen mengalami peningkatan sebesar 0,299 satuan.

\section{Pengujian Hipotesis}

Tabel 6. Hasil Uji Simultan (Uji F)

\begin{tabular}{clcccc}
\hline \hline No & \multicolumn{1}{c}{ Hubungan Variabel } & $\mathbf{F}_{\text {hitung }}$ & $\mathbf{F}_{\text {tabel }}$ & $\begin{array}{c}\text { Sig. } \\
\mathbf{F}_{\text {hitung }}\end{array}$ & Kriteria \\
\hline 1 & $\begin{array}{l}\text { Pengaruh Sertifikasi Dosen dan Motivasi } \\
\text { Kerja Terhadap Kepuasan Kerja } \\
2\end{array}$ & 9.984 & 3.108 & 0.000 & Signifikan \\
& $\begin{array}{l}\text { Pengaruh Sertifikasi Dosen dan Motivasi } \\
\text { Kepuasan Kerja }\end{array}$ & 23.633 & 2.717 & 0.000 & Signifikan \\
\hline
\end{tabular}

Sumber : Data primer yang diolah 2017

\section{Pengaruh Sertifikasi Dosen dan Motivasi Kerja Terhadap Kepuasan Kerja Dosen pada Universitas Swasta di Kota Palembang \\ Dari hasil perhitungan pertama} diperoleh $F_{\text {hitung }}=9,984$, sedangkan $F_{\text {tabel }}$ diperoleh sebesar 3,108. Dengan demikian F Fitung $>F_{\text {tabel }}(9,984>3,108)$ dan tingkat signifikansinya $(0,000<$ $0,05)$ sehingga persamaan regrezi $Z$ atas $\mathrm{X} 1, \mathrm{X} 2$ berarti secara simultan sertifikasi dosen dan motivasi kerja berpengaruh signifikan terhadap kepuasan kerja dosen Universitas Swasta di Kota Palembang. Besarnya tingkat pengaruh kedua variabel ini secara bersama-sama mengalami kenaikan maka akan berdampak pada kenaikan tingkat kepuasan kerja dosen, begitu pula sebaliknya.

Berdasarkan hasil analisis dengan menggunakan analisis jalur, variabel sertifikasi dosen memiliki koefisien path sebesar 0,365 dan variabel motivasi kerja memiliki koefisien path sebesar 0,211. Hasil analisis jalur menunjukkan bahwa variabel sertifikasi dosen dan motivasi kerja merupakan salah satu faktor yang memiliki pengaruh langsung yang positif dan signifikan terhadap kepuasan kerja pada Universitas Swasta di Kota Palembang. 


\section{Pengaruh Sertifikasi Dosen, Motivasi Kerja Terhadap Kinerja Dosen melalui kepuasan kerja pada Universitas Swasta di Kota Palembang}

Hasil perhitungan kedua diperoleh Fhitung $=23,633$, sedangkan $F_{\text {tabel }}$ diperoleh sebesar 2,717. Dengan demikian $F_{\text {hitung }}>F_{\text {tabel }}(23,633>$ 2,717 ) dan tingkat signifikansinya $(0,000<0,05)$ sehingga secara simultan sertifikasi dosen, motivasi kerja dan kepuasan kerja berpengaruh signifikan terhadap kinerja dosen Universitas Swasta di Kota Palembang. Besarnya tingkat pengaruh ketiga variabel ini secara bersama-sama mengalami kenaikan maka akan berdampak pada kenaikan tingkat kinerja dosen, begitu pula sebaliknya.

Berdasarkan hasil pengujian menunjukkan sertifikasi dosen berpengaruh positif dan signifikan terhadap kepuasan kerja dan kepuasan kerja berpengaruh positif dan signifikan terhadap kinerja dosen, dengan koefisien path sebesar 0,109 sehingga diperoleh pengaruh total dari sertifikasi dosen terhadap kinerja dosen dan sertifikasi dosen terhadap kinerja dosen melalui kepuasan kerja sebesar 0,535.

Dari hasil tersebut ditemukan bahwa pengaruh total sertifikasi dosen melalui kepuasan kerja terhadap kinerja dosen lebih besar dibanding pengaruh langsung sertifikasi dosen terhadap kinerja dosen sebesar 0,426 $(0,535>0,426)$. Temuan tersebut dapat disimpulkan bahwa kepuasan kerja merupakan variabel intervening atau mediating dari sertifikasi dosen terhadap kinerja dosen pada Universitas Swasta di Kota Palembang. Oleh karena itu, upaya untuk meningkatkan kinerja dosen Universitas Swasta di Kota Palembang sebaiknya meningkatkan kepuasan kerja terlebih dahulu.

Hasil pengujian hipotesis motivasi kerja terhadap kinerja dosen melalui kepuasan kerja menunjukkan bahwa motivasi kerja berpengaruh positif dan signifikan terhadap kepuasan kerja dan kepuasan kerja berpengaruh positif dan signifikan terhadap kinerja dosen, dengan koefisien path sebesar 0,063, sehingga diperoleh pengaruh total dari motivasi kerja terhadap kinerja dosen dan motivasi kerja terhadap kinerja dosen melalui kepuasan kerja sebesar 0,273 .

Dari hasil tersebut ditemukan bahwa pengaruh total motivasi kerja melalui kepuasan kerja terhadap kinerja dosen lebih besar dibanding pengaruh langsung motivasi kerja terhadap kinerja dosen $(0,273>$ 0,210). Temuan tersebut dapat disimpulkan bahwa kepuasan kerja merupakan variabel intervening atau mediating dari motivasi kerja terhadap kinerja dosen pada Universitas Swasta di Kota Palembang. Oleh karena itu, upaya untuk meningkatkan kinerja dosen Universitas Swasta di Kota Palembang sebaiknya meningkatkan kepuasan kerja terlebih dahulu.

Tabel 7. Hasil Uji Parsial (Uji t)

\begin{tabular}{cccccc}
\hline \hline Struktural & $\begin{array}{c}\text { Koefisien } \\
\text { Jalur }\end{array}$ & $\mathbf{t}_{\text {hitung }}$ & $\mathbf{t}_{\text {tabel }}$ & $\mathbf{p}$-value & Kesimpulan \\
\hline $\mathrm{P}_{x 1 z}$ & 0,365 & 3,567 & 1,989 & 0,000 & Signifikan \\
$\mathrm{P}_{x 2 z}$ & 0,211 & 2,120 & 1,989 & 0,037 & Signifikan \\
$\mathrm{P}_{x 1 y}$ & 0,426 & 4,829 & 1,999 & 0,000 & Signifikan \\
$\mathrm{P}_{x 2 y}$ & 0,210 & 2,504 & 1,999 & 0,014 & Signifikan \\
$\mathrm{P}_{z y}$ & 0,299 & 3,305 & 1,999 & 0,001 & Signifikan \\
\hline
\end{tabular}

Sumber : Data primer yang diolah 2017 


\section{Pengaruh Sertifikasi Dosen terhadap Kepuasan Kerja}

Berdasarkan hasil perhitungan diperoleh angka thitung sebesar 3,567 > tabel sebesar 1,989 maka Ho ditolak dan $\mathrm{Ha}$ diterima, yang berarti ada pengaruh antara sertifikasi dosen terhadap kepuasan kerja dosen pada Universitas Swasta di Kota Palembang. Besarnya pengaruh sertifikasi dosen terhadap kepuasan kerja dosen sebesar 0,365 atau $36,6 \%$ dianggap signifikan. Hal ini tercermin pada angka signifikansi sebesar 0,000 yang lebih kecil dari 0,05. Hasil analisis jalur menunjukkan bahwa variabel sertifikasi dosen merupakan salah satu faktor yang memiliki pengaruh secara langsung yang positif dan signifikan terhadap kepuasan kerja pada Universitas Swasta di Kota Palembang. Temuan penelitian ini sesuai dengan penelitian Siswanto, Victorianus Aries dkk (2015) menemukan bahwa ada pengaruh pemberian sertifikasi dosen terhadap Kepuasan.

\section{Pengaruh Motivasi Kerja terhadap Kepuasan Kerja}

Berdasarkan hasil perhitungan diperoleh angka thitung sebesar 2,120 > tabel sebesar 1,989 maka Ho ditolak dan $\mathrm{Ha}$ diterima, yang berarti ada pengaruh antara motivasi kerja terhadap kepuasan kerja dosen pada Universitas Swasta di Kota Palembang. Besarnya pengaruh motivasi kerja terhadap kepuasan kerja dosen sebesar 0,211 atau $21,1 \%$ dianggap signifikan. Hal ini tercermin pada angka signifikansi sebesar 0,037 yang lebih kecil dari 0,05. Hasil analisis jalur menunjukkan bahwa variabel motivasi kerja merupakan salah satu faktor yang memiliki pengaruh secara langsung yang positif dan signifikan terhadap kepuasan kerja pada
Universitas Swasta di Kota Palembang. Temuan penelitian ini tidak sesuai dengan penelitian Siswanto, Victorianus Aries dkk (2015) menemukan bahwa motivasi tidak berpengaruh terhadap kepuasan

\section{Pengaruh Sertifikasi Dosen terhadap Kinerja Dosen}

Berdasarkan hasil perhitungan diperoleh angka thitung sebesar 4,829 > ttabel sebesar 1,999 maka Ho ditolak dan $\mathrm{Ha}$ diterima, yang berarti ada pengaruh antara sertifikasi dosen terhadap kinerja dosen pada Universitas Swasta di Kota Palembang. Besarnya pengaruh sertifikasi dosen terhadap kinerja dosen sebesar 0,426 atau $42,6 \%$ dianggap signifikan. Hal ini tercermin pada angka signifikansi sebesar 0,000 yang lebih kecil dari 0,05. Hasil analisis jalur menunjukkan bahwa variabel sertifikasi dosen merupakan salah satu faktor yang memiliki pengaruh secara langsung yang positif dan signifikan terhadap kinerja dosen pada Universitas Swasta di Kota Palembang. Temuan penelitian ini sesuai dengan penelitian Murwati (2013), Romli (2012), Partono \& Nurmawati, Ira (2010), Zulkifli , dkk (2014), Suwandi (2012), Kanto (2015) serta Istiarini, R. \& Sukanti. (2012) bahwa terdapat pengaruh antara sertifikasi terhadap kinerja dosen.

\section{Pengaruh Motivasi Kerja terhadap Kinerja Dosen}

Berdasarkan hasil perhitungan diperoleh angka thitung sebesar 2,504 > tabel sebesar 1,999 maka Ho ditolak dan $\mathrm{Ha}$ diterima, yang berarti ada pengaruh antara motivasi kerja terhadap kinerja dosen pada Universitas Swasta di Kota Palembang. Besarnya pengaruh motivasi kerja terhadap kinerja dosen sebesar 0,210 atau $21 \%$ dianggap 
signifikan. Hal ini tercermin pada angka signifikansi sebesar 0,014 yang lebih kecil dari 0,05. Hasil analisis jalur menunjukkan bahwa variabel motivasi kerja merupakan salah satu faktor yang memiliki pengaruh secara langsung yang positif dan signifikan terhadap kinerja dosen pada Universitas Swasta di Kota Palembang. Temuan penelitian ini sesuai dengan penelitian Indrarini (2009), Zulkifli , dkk (2014), Suwandi (2012), Kanto (2015) serta Istiarini, R. \& Sukanti (2012) menyatakan bahwa ada pengaruh motivasi kerja terhadap kinerja dosen. Berbeda dengan hasil penelitian yang dilakukan oleh Syahalam, dkk (2013), hasil penelitiannya menunjukkan bahwa motivasi tidak berpengaruh terhadap kinerja.

\section{Pengaruh Kepuasan Kerja terhadap Kinerja Dosen}

Berdasarkan hasil perhitungan diperoleh angka thitung sebesar 3,305 > ttabel sebesar 1,999 maka Ho ditolak dan $\mathrm{Ha}$ diterima, yang berarti ada pengaruh antara kepuasan kerja terhadap kinerja dosen pada Universitas Swasta di Kota Palembang. Besarnya pengaruh kepuasan kerja terhadap kinerja dosen sebesar 0,299 atau 29,9\% dianggap signifikan. Hal ini tercermin pada angka signifikansi sebesar 0,001 yang lebih kecil dari 0,05. Hasil analisis jalur menunjukkan bahwa variabel kepuasan kerja merupakan salah satu faktor yang memiliki pengaruh secara langsung yang positif dan signifikan terhadap kinerja dosen pada Universitas Swasta di Kota Palembang. Temuan penelitian ini sesuai dengan penelitian Indrarini (2009), Syahalam, dkk (2013), Diana (2012) serta Kanto (2015) menyatakan bahwa kepuasan kerja berpengaruh terhadap kinerja dosen. Berbeda dengan penelitian Siswanto, Victorianus Aries dkk (2015) menemukan bahwa kepuasan kerja tidak berpengaruh terhadap kinerja dosen.

Tabel 8. Pengaruh Langsung dan Pengaruh Tidak Langsung serta Pengaruh Total $X_{1}, X_{2}, Z$ dan $Y$

\begin{tabular}{cccc}
\hline \hline $\begin{array}{c}\text { Pengaruh } \\
\text { Variabel }\end{array}$ & $\begin{array}{c}\text { Pengaruh } \\
\text { Langsung }\end{array}$ & $\begin{array}{c}\text { Pengaruh Tidak Langsung Melalui } \\
\text { Kepuasan Kerja (Z) }\end{array}$ & Pengaruh Total \\
\hline $\mathrm{X}_{1} \rightarrow \mathrm{Z}$ & 0,365 & & 0,365 \\
$\mathrm{X}_{2} \rightarrow \mathrm{Z}$ & 0,211 & & 0,211 \\
$\mathrm{X}_{1} \rightarrow \mathrm{Y}$ & 0,426 & $0,365 \times 0,299=0,109$ & 0,535 \\
$\mathrm{X}_{2} \rightarrow \mathrm{Y}$ & 0,210 & $0,211 \times 0,299=0,063$ & 0,273 \\
$\mathrm{Z} \rightarrow \mathrm{Y}$ & 0,299 & & 0,299 \\
\hline
\end{tabular}

Sumber : Data primer yang diolah 2017

Pengaruh Langsung (Direct Effect)

Pengaruh langsung adalah pengaruh dari satu variable independen ke variable dependen, tanpa melalui variable dependen lainnya.

\section{Pengaruh Langsung Sub-Struktural}

Pada persamaan sub-struktural dan dari hasil analisis jalur dapat diketahui bahwa sertifikasi dosen memiliki pengaruh langsung yang lebih besar $(0,365)$ dibanding motivasi kerja $(0,211)$ terhadap kepuasan kerja Universitas Swasta di Kota Palembang. Sertifikasi dosen dan motivasi kerja dosen sama-sama memiliki pengaruh yang signifikan karena masing-masing nilai thitung > 1,989. Dengan demikian, upaya untuk 
mempercepat peningkatan kepuasan kerja pada Universitas Swasta di Kota Palembang dapat dilakukan melalui peningkatan sertifikasi dosen terlebih dahulu, baru prioritas selanjutnya motivasi kerja dosen.

\section{Pengaruh Langsung Struktural}

Pada persamaan struktural dan dari hasil analisis jalur dapat diketahui bahwa sertifikasi dosen $(0,426)$ memiliki pengaruh langsung yang paling dominan terhadap kinerja dosen pada Universitas Swasta di Kota Palembang dibanding pengaruh langsung kepuasan kerja $(0,299)$ dan motivasi kerja $(0,210)$. Sertifikasi dosen, motivasi kerja dan kepuasan kerja sama-sama memiliki pengaruh yang signifikan karena masing-masing memiliki nilai thitung $>1,999$. Hal ini menandakan bahwa untuk meningkatkan kinerja dosen, upaya yang harus diprioritaskan adalah melalui peningkatan sertifikasi dosen, selanjutnya meningkatkan kepuasan kerja baru kemudian meningkatkan motivasi kerja para dosen Universitas Swasta di Kota Palembang.

\section{Pengaruh Tidak Langsung (Indirect Effect) dan Pengaruh Total (Total Effect)}

Pengaruh tidak langsung adalah situasi dimana variable independen mempengaruhi variable dependen melalui variable lain yang disebut variable intervening (intermediary).

\section{Pengaruh Sertifikasi Dosen Terhadap Kinerja Dosen melalui Kepuasan Kerja}

Berdasarkan hasil pengujian persamaan substruktur pertama dan persamaan struktural kedua menunjukkan sertifikasi dosen berpengaruh positif dan signifikan terhadap kepuasan kerja dan kepuasan kerja berpengaruh positif dan signifikan terhadap kinerja dosen, dengan pengaruh tidak langsung sebesar 0,365 $\times 0,299=0,109$, sehingga diperoleh pengaruh total dari sertifikasi dosen terhadap kinerja dosen $(0,426)$ dan sertifikasi dosen terhadap kinerja dosen melalui kepuasan kerja sebesar 0,426+0,109 $=0,535$.

Dari hasil perhitungan di atas ditemukan bahwa pengaruh total sertifikasi dosen melalui kepuasan kerja terhadap kinerja dosen lebih besar dibanding pengaruh langsung sertifikasi dosen terhadap kinerja dosen $(0,535>0,426)$. Temuan tersebut dapat disimpulkan bahwa kepuasan kerja merupakan variabel intervening atau mediating dari sertifikasi dosen terhadap kinerja dosen pada Universitas Swasta di Kota Palembang. Oleh karena itu, upaya untuk meningkatkan kinerja dosen Universitas Swasta di Kota Palembang sebaiknya meningkatkan kepuasan kerja terlebih dahulu.

\section{Pengaruh Motivasi Kerja Terhadap Kinerja Dosen melalui Kepuasan Kerja}

Berdasarkan hasil pengujian persamaan substruktur pertama dan persamaan struktural kedua menunjukkan motivasi kerja berpengaruh positif dan signifikan terhadap kepuasan kerja dan kepuasan kerja berpengaruh positif dan signifikan terhadap kinerja dosen, dengan pengaruh tidak langsung sebesar 0,211 $\times 0,299=0,063$, sehingga diperoleh pengaruh total dari motivasi kerja terhadap kinerja dosen $(0,210)$ dan motivasi kerja terhadap kinerja dosen melalui kepuasan kerja sebesar 0,210 +0,063 =0,273.

Dari hasil perhitungan di atas ditemukan bahwa pengaruh total motivasi kerja melalui kepuasan kerja terhadap kinerja dosen lebih besar 
dibanding pengaruh langsung motivasi kerja terhadap kinerja dosen $(0,273>$ 0,210). Temuan tersebut dapat disimpulkan bahwa kepuasan kerja merupakan variabel intervening atau mediating dari motivasi kerja terhadap kinerja dosen pada Universitas Swasta di Kota Palembang. Oleh karena itu, upaya untuk meningkatkan kinerja dosen Universitas Swasta di Kota Palembang sebaiknya meningkatkan kepuasan kerja terlebih dahulu.

Gambar 2 menunjukkan diagram jalur pengaruh langsung dan pengaruh tidak langsung serta pengaruh total antar variabel.

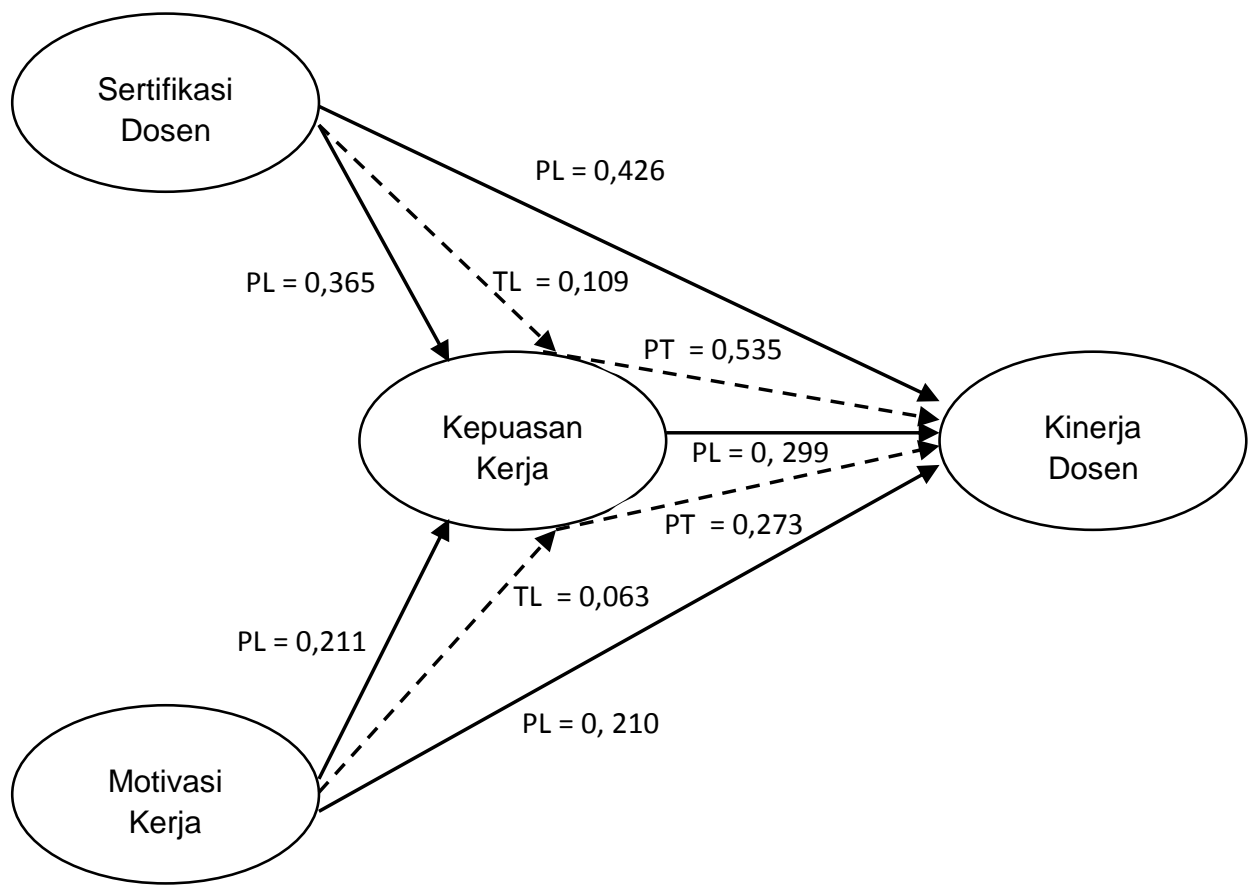

\section{Keterangan :}

$\mathrm{PL}=$ Pengaruh langsung dengan garis penuh (full line)

$\mathrm{TL}=$ Pengaruh tidak langsung dengan garis putus-putus (dot line)

PT = Pengaruh total $($ Total Effect $)$

Gambar 2. Koeifisen Pengaruh Langsung dan Tidak Langsung serta Pengaruh Total

\section{KESIMPULAN DAN SARAN Kesimpulan}

Berdasarkan hasil analisis dan pengujian hipotesis dapat ditarik beberapa kesimpulan sebagai berikut:

1. Terdapat pengaruh positif dan signifikan sertfikasi dosen terhadap kepuasan kerja dosen Universitas Swasta di Kota Palembang. Besarnya pengaruh sertfikasi dosen terhadap kepuasan kerja sebesar 0,365.

2. Terdapat pengaruh positif dan signifikan motivasi kerja terhadap kepuasan kerja dosen Universitas Swasta di Kota Palembang. Besarnya pengaruh motivasi kerja terhadap kepuasan kerja sebesar 0,211 .

3. Terdapat pengaruh positif dan signifikan sertfikasi dosen dan motivasi kerja secara bersamasama terhadap kepuasan kerja dosen Universitas Swasta di Kota Palembang. Hal ini ditunjukkan dengan persamaan sub-struktural : kepuasan kerja $=0,365$ sertifikasi dosen $+0,211$ motivasi kerja, 
errorvar $=0,824 R^{2}=176$. Variabel yang paling dominan mempengaruhi kepuasan kerja adalah sertifikasi dosen, baru setelah itu motivasi kerja.

4. Terdapat pengaruh positif dan signifikan sertfikasi dosen terhadap kinerja dosen Universitas Swasta di Kota Palembang. Besarnya pengaruh sertfikasi dosen terhadap kinerja dosen sebesar 0,426 .

5. Terdapat pengaruh positif dan signifikan motivasi kerja terhadap kinerja dosen Universitas Swasta di Kota Palembang. Besarnya pengaruh motivasi kerja terhadap kinerja dosen sebesar 0,210.

6. Terdapat pengaruh positif dan signifikan kepuasan kerja terhadap kinerja dosen Universitas Swasta di Kota Palembang. Besarnya pengaruh kepuasan kerja terhadap kinerja dosen sebesar 0,299.

7. Terdapat pengaruh positif dan signifikan sertfikasi dosen, motivasi kerja dan kepuasan kerja secara bersama-sama terhadap kinerja dosen Universitas Swasta di Kota Palembang. Hal ini ditunjukkan dengan persamaan struktural : kinerja dosen $=0,426$ sertifikasi dosen $+0,211$ motivasi kerja + 0,210 kepuasan kerja, errorvar $=$ $0,553 R^{2}=447$. Variabel yang paling dominan mempengaruhi kinerja dosen adalah sertifikasi dosen, kemudian kepuasan kerja dan terakhir motivasi kerja.

\section{Saran}

Berdasarkan hasil temuan dan analisis serta kesimpulan, maka pada bagian selanjutnya akan dikemukakan beberapa saran yang dapat dijadikan sebagai bahan pertimbangan untuk para dosen dan pejabat pengambil kebijakan dalam rangka meningkatkan kinerja dosen pada Universitas Swasta di Kota Palembang.

1. Untuk meningkatkan kepuasan kerja dosen, dapat dilakukan dengan meningkatkan sertifikasi dosen terlebih dahulu dengan mempunyai koefisien paling tinggi sebesar 0,365, baru setelah itu motivasi kerja dengan mempunyai koefisien paling rendah 0,211.

2. Untuk meningkatkan kinerja dosen, dapat dilakukan dengan meningkatkan sertifikasi dosen terlebih dahulu dengan mempunyai koefisien paling tinggi sebesar 0,365 , kemudian kepuasan kerja dengan nilai koefisien sebesar 0,299 dan baru setelah itu motivasi kerja dengan mempunyai koefisien paling rendah 0,211.

\section{DAFTAR PUSTAKA}

Anoraga, Panji. 2014. Psikologi Kerja. Cetakan 6. Jakarta: Rineka Cipta.

Bangun, W. 2012. Manajemen Sumber Daya Manusia. Erlangga : Jakarta.

Diana, Ana. 2012. Pengaruh Kepuasan Kerja Terhadap Kinerja Dosen Universitas Singaperbangsa Karawang. Jurnal Manajemen Vol. 09. No.2 Januari 2012.

Hasibuan S.P. Malayu H. 2013. Manajemen Dasar Pengertian dan Masalah.Jakarta : PT. Bumi Aksara.

Indrarini. 2009. Pengaruh Motivasi dan Kepuasan Kerja Terhadap Kinerja Dosen Akademi Swasta di Kota Semarang. Tesis. Program Pascasarjana Program Studi Manajemen Pendidikan Universitas Negeri Semarang.

Istiarini, R. \& Sukanti. 2012. Pengaruh Sertifikasi Guru dan Motivasi Kerja Guru Terhadap Kinerja Guru SMA Negeri 1 Sentolo 
Kabupaten Kulon Progo. Jurnal Pendidikan Akuntansi Indonesia,Vol. X, 98-113.

Kanto, Kulasse. 2015. Pengaruh Sertifikasi Terhadap Motivasi Kerja, Kepuasan Kerja \& Kinerja Guru BK SMAN. Journal of EST, ISSN : 24601497, Volume 1, Nomor 2,.September 2015 hal $61-73$.

Melati, F.K. Susilaningsih, Sohidin. 2013. Pengaruh Sertifikasi Guru Dan Motivasi Kerja Guru Terhadap Kinerja Guru SMA N 5 Surakarta. Jurnal Jupe UNS, Vol. 2 No. 1, Juli 2013 hal 7182.

Murwati, Hesti. 2013. Pengaruh Sertifikasi Profesi Guru Terhadap Motivasi Kerja dan Kinerja Guru di SMK Negeri Se-Surakarta. Jurnal Pendidikan Bisnis dan Ekonomi (BISE). Vol.1 No. 1 Tahun 2013.

Pardede, Ratlan dan Manurung, Renhard. 2014. Analisis Jalur (Path Analysis) Teori dan Aplikasi dalam Riset Bisnis. Rineka Cipta: Jakarta.

Partono dan Ira Nurmawati. 2010. Pengaruh Sertifikasi Guru Dalam Jabatan Melalui Penilaian Portofolio Terhadap Kinerja Guru Bersertifikat di SMA Negeri Kabupaten Magelang (Kompensasi Sebagai Variable Intervening). Jurnal Pendidikan Ekonomi Dinamika Pendidikan. Vol. V, No. 1, Juni 2010, hal. $43-55$.

Rivai, Veithzal. 2009. Manajemen Sumber Daya Manusia untuk Perusahaan : Dari Teori ke Praktek.Jakarta : Rajawali Pers

Romli. 2012. Pengaruh Sertifikasi Guru Terhadap Peningkatan Kinerja Guru Pada Madrasah Aliyah
Negeri Kota Kediri 3. Jurnal IImu Manajemen, Revitalisasi. Vol. 1, No. 1. 31-45.

Suwandi. 2012. Pengaruh Sertifikasi Dosen dan Motivasi Kerja Terhadap Kinerja Dosen di Lingkungan Perguruan Tinggi Kota Semarang, IKIP PGRI Semarang.

Syahalam, Endy. Sigit Nugroho, Nasution. 2013. Pengaruh Motivasi Keria, Kepuasan Kerja, Imbalan Terhadap Kinerja Dosen Sertifikasi Dalam Melaksanakan Proses Belajar Mengajar di Poltekkes Kemenkes Bengkulu Tahun Akademik 2012/2013. The Manager Review. Jurnal IImiah Manajemen. ISSN: 1979-2239. Volume 15, Nomor 3, Oktober 2013.

Undang-Undang Republik Indonesia nomor 14 Tahun 2005 tentang Guru dan Dosen.

Zulkifli, Moh. Arif Darmawan. Edy Sutrisno. 2014. Motivasi Kerja, Sertifikasi, Kesejahteraan dan Kinerja Guru. Persona, Jurnal Psikologi Indonesia., Vol. 3, No. 02, Mei 2014 hal 148 155. 